\title{
Estimating the Phosphate Fertilizer Need of Soybean (Glycine Max (L) Merr.) In Some Ultisols In Benue State, Nigeria From Their Solution Phosphate Concentration
}

\author{
Bemgba Anjembe ${ }^{1}$, O. Olatunji ${ }^{2}$ and C.O Adejuyigbe ${ }^{3}$ \\ ${ }^{1,2}$ Department of Soil Science, Federal University of Agriculture, Makurdi, Nigeria \\ ${ }^{3}$ Department of Soil Science and Land management, Federal University of Agriculture, Abeokuta, Nigeria
}

\begin{abstract}
Ultisols in Benue state were studied to determine the solution phosphate concentration (SPC) required to obtain optimum yield of soybean for estimating the $P$ fertilizer requirement of soybean. Soil inorganic $P$ was fractionated using standard procedures. Sorption characteristics were determined in $0.01 \mathrm{M}$ $\mathrm{CaCl}_{2}$ solutions of various $P$ concentrations. Amounts of $P$ that gave $0.025,0.05,0.075,0.100,0.125,0.150$, $0.175,0.200,0.225,0.250 \mathrm{mg} \mathrm{kg}^{-1}$ solution concentration were estimated from adsorption curves. In the greenhouse, $4 \mathrm{~kg}$ of soil from each location was placed in plastic pots. $\mathrm{P}$ estimated was added as $\mathrm{KH}_{2} \mathrm{PO}_{4}$. Treatments were laid out in Randomized Complete Block Design. Soybean (TGx 1448-2E) was planted to maturity. The shoot was dried, weighed, milled and digested in a 4:1 $\mathrm{HNO}_{3}: \mathrm{HClO}_{4}$ mixture and analyzed for $\mathrm{P}$. $S P C$ was determined in relation to yield. Field trial was conducted at Vanam and phosphate fertilizer quantity that resulted in 0.0, 0.5 SPC, 1.0 SPC, and 2.0 SPC was added per plot, seeds were drilled and replicated thrice. At harvest, SPC that gave highest grain yield was evaluated and the quantity of $P$ required (SPR) to achieve this concentration was calculated. High grain yield was obtained at Vanam and Abaji-Kpav at SPC of

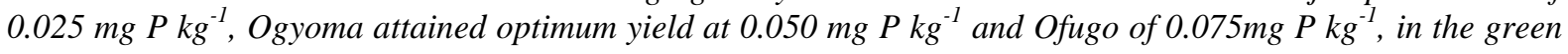
house experiment. The estimated SPC value gave high grain yield in the field trial. Highest P fertilization would be required at Ofugo while Vanam would require the least.
\end{abstract}

Key words: solution, phosphate, concentration, fertilization, ultisols, optimum, yield

\section{Introduction}

Phosphorus is one of the major nutrient elements. Its importance as a yield limiting nutrient element is well established (Udo and Ogunwale 1977; Uzu et al., 1975; Enwezor and Moore 1966). This is particularly so in tropical soils that are variously described as well weathered that has the ability to fix phosphorus Adetunji, (1996).

Soil solution contains very low concentrations of $\mathrm{P}$ as compared to plant requirements, continuous replenishment of this pool to avoid P deficiency is therefore, necessary. The labile $\mathrm{P}$ fraction serves this purpose. The labile soil $\mathrm{P}$ consists of $\mathrm{P}$ weakly adsorbed on to soil surfaces. This fraction is in equilibrium with solution $\mathrm{P}$ and is considered to be potentially available for plant use. The concentration of $\mathrm{P}$ in this fraction could be10 to 100 times greater than that in solution. Depending on time and soil $\mathrm{P}$ characteristics, the labile pool can become more stable and move into non labile pool (Barrow and Shaw, 1975 ${ }^{\mathrm{a}}$ ). Since the labile P can easily revert to the non labile fraction, determination of the actual $\mathrm{P}$ concentration in solution that can sustain optimum yield is necessary so as to avoid wastages and to continuously replenish the solution P pool throughout the growing season. This solution P concentration (SPC), is defined as the optimum solution P concentration required to achieve $95 \%$ maximum yield.

Soybean, Glycine $\max (L)$ Merr. is an annual leguminous crop grown mainly for its oil and protein content. In Nigeria, an estimated 50,000 hectares of the crop is cultivated annually, most of this being in Benue State (Aduayi et al.,eds. 2002). Farmers' yields average $300-1,030 \mathrm{~kg} \mathrm{ha}^{-1}$ of threshold grain. Under research conditions, yields of over $3000 \mathrm{~kg} \mathrm{ha}^{-1}$ have been recorded. Higher yield values and better quality of the crop are probable if phosphate interaction in soils is well understood and properly managed as $\mathrm{P}$ is the limiting nutrient element for the production of this crop. This is particularly so as Benue State falls in the Northern Guinea Savannah area of the tropics and the soils are highly weathered with its attendant effect on phosphorus fixation.

This study is therefore undertaken with the following objectives:

To determine the solution phosphate concentration needed for optimum yield of soybean in some Ultisols in Benue state.

To determine the amount of fertilizer $\mathrm{P}$ that would be required to achieve this solution $\mathrm{P}$ concentration. 


\section{Materials And Methods}

The study involved laboratory, pot and field experiments.

Surface soil samples $(0-20 \mathrm{~cm})$ were collected from four locations in Benue State from the soil type of Alfisols as shown in table 1.The soil samples were air dried and passed through a $2 \mathrm{~mm}$ sieve for Laboratory studies and pot experiment.

$\mathrm{pH}$ was determined by the glass electrode in a 1:2 soil, water suspension. Particle size analysis was determined by the hydrometer method of Bouyoucos, (1951), Organic carbon by the Chromic acid oxidation procedure of Walkley and Black (1934), Exchangeable bases by the neutral ammonium acetate saturation, $\mathrm{Na}$ and $\mathrm{K}$ in the extracts were determined by the flame photometer while $\mathrm{Ca}$ and $\mathrm{Mg}$ were determined by the Atomic Absorption Spectrophotometer. Exchangeable acidity by the $1 \mathrm{M} \mathrm{KCl}$ extraction and $0.01 \mathrm{M} \mathrm{NaOH}$ titration. Nitrogen in the samples was determined by the regular macro- Kjeldahl method.

Phosphorus fractionation was done by the modified procedure of Chang and Jackson (1957) as modified by Peterson and Corey (1966) and reported by Page et al., (1982). Total and organic P was determined by the $\mathrm{NaOH}$ digestion method (Mehra et al., 1954). Available $\mathrm{P}$ was extracted by $0.5 \mathrm{M} \mathrm{NaHCO}_{3}$ buffered at pH 8.5 Olsen et al., (1954), and by $0.03 \mathrm{M} \mathrm{NH} \mathrm{NH}_{4} \mathrm{~F} 0.025 \mathrm{M} \mathrm{HCl}$, Bray and Kutz, (1945). Phosphorus in the extracts was determined colorimetrically by the Ascorbic acid method of Murphy and Riley, (1962) as modified by Watanabe and Olsen, (1965) and reported by Page et al., (1982). Free Fe and Al oxides (Total oxides) were extracted by the citrate dithionate-bicarbonate method, Mebra and Jackson (1960). Extractable Fe and Al in the extracts were determined with an atomic absorption spectrophotometer.

Phosphate sorption characteristics of the soils were determined by placing eight separate $5 \mathrm{~g}$ subsamples of sieved soils in $50 \mathrm{ml}$ polypropylene centrifuge tubes. Volumes of $40 \mathrm{~cm}^{3}$ of $0.01 \mathrm{M} \mathrm{CaCl}_{2}$ solution containing $0,15,25,40,100,200,400$ and $800 \mathrm{mg} \mathrm{l}^{-1} \mathrm{P}_{\text {as }} \mathrm{KH}_{2} \mathrm{PO}_{4}$ were distributed to the tubes as described by Dear et al., (1992). The samples were then shaken for $24 \mathrm{hrs}$ and then centrifuged for ten minutes at $1200 \mathrm{rpm}$ at $4^{\circ} \mathrm{C}$ in a refrigerated centrifuge. The supernatant was filtered through a Whatman's filter paper. $\mathrm{P}$ in solution was determined by a modification of the Murphy and Riley method (Watanabe and Olsen, 1965). A plot of P in equilibrium (supernatant) solution was constructed against the amount of P added. Phosphate sorbed (ps) was calculated as the difference between the concentration of the added $\mathrm{P}$ and the $\mathrm{P}$ in solution.

\section{Pot experiment}

Four Kg of the $2 \mathrm{~mm}$ sieved soil from each location was placed in each of the 33 plastic pots. For each soil the amount of $\mathrm{P}$ that was equivalent to the following levels of solution $\mathrm{P}$ concentration in the soils 0.025 , $0.05,0.075,0.100,0.125,0.150,0.175,0.200,0.225,0.250 \mathrm{mg} \mathrm{kg}^{-1}$, was added as $\mathrm{KH}_{2} \mathrm{PO}_{4}$ in $50 \mathrm{~cm}^{3}$ of distilled water and mixed thoroughly. The amounts of $\mathrm{P}$ were estimated for each soil.

\begin{tabular}{|c|c|c|}
\hline S/No & LOCATION & SOIL CLASS \\
\hline 1 & Ogyoma & $\begin{array}{l}\text { Oxic haplustult (USDA) } \\
\text { Orthic acrisol (FAO) }\end{array}$ \\
\hline 2 & Ofugo & $\begin{array}{l}\text { Oxic haplustult (USDA) } \\
\text { Orthic acrisol (FAO) }\end{array}$ \\
\hline 3 & Abaji-Kpav & $\begin{array}{l}\text { Oxic haplustult (USDA) } \\
\text { Orthic acrisol (FAO) }\end{array}$ \\
\hline 4 & Vanam & $\begin{array}{l}\text { Typic paleustult (USDA) } \\
\text { Dystric nitosol (FAO) }\end{array}$ \\
\hline
\end{tabular}

Federal Department of Agricultural Land Resources (FDALR, 1990)

All the pots initially received equivalents of $60 \mathrm{Kg} \mathrm{N} \mathrm{ha}^{-1}$ as urea, and $30 \mathrm{Kg} \mathrm{ha}^{-1} \mathrm{~K}$ (Yusuf and Idowu, 2001 ) as $\mathrm{KCl}$. There were pots without $\mathrm{P}$ addition that served as control. Three soybean seeds were planted per pot and later thinned to two and the pots were laid out in a Randomized Complete Block Design (RCBD) and the crop was grown to maturity with the normal agronomic practices carried out.

At harvest the above ground plant material was dried and weighed. The plant materials were milled and digested in a 4:1 $\mathrm{HNO}_{3}: \mathrm{HClO}_{4}$ mixture and analyzed for $\mathrm{P}$ using the method of Murphy and Riley (1962). The optimum solution concentration was determined for each soil both in terms of grain and dry matter yield by subjecting the yield data to the analysis of variance with the view to determine the solution concentration that gave maximum yield. The critical equilibrium concentration (SPC) was estimated as the amount of P in an equilibrium concentration needed to achieve maximum yield. The Standard Phosphate Requirement (SPR) was estimated as the amount of fertilizer $\mathrm{P}$ that gave the equilibrium solution concentration required to achieve maximum yield. 


\section{Field trials}

Field trial was conducted at Vanam. The experimental site was ploughed and harrowed. The size of each treatment plot was $5 \mathrm{~m} \mathrm{X} 5 \mathrm{~m}$ and each plot was treated with equivalents of $60 \mathrm{Kg} \mathrm{ha}^{-1} \mathrm{~N}$ as Urea, $30 \mathrm{Kg}$ $\mathrm{ha}^{-1} \mathrm{~K}$ as KCl. Phosphate fertilizer quantity that resulted in 0, 0.5 SPC, SPC, and 2 SPC (as estimated from the pot experiment) was added per plot and the four treatments were replicated three times in a randomized complete block design (RCBD). Soybean seeds of the variety TGX 1448-2E were drilled into the various plots. At harvest, the soybean grains were dried and weighed. For each location, data generated was subjected to the analysis of variance and the solution concentration that gave the best yield was taken as the SPC. The solution P concentration that gave maximum grain yield was evaluated for each soil and the quantity of P required (SPR) to achieve this solution concentration was calculated for each soil.

Agronomic data collected was: Dry matter yield at harvest in both the pot and field experiments, number of pods per plant, weight of seeds per pot/plot and one hundred seed weight per pot/plot. Data generated was subjected to the analysis of variance. Means were separated using the Duncan multiple range test (DMRT). The SAS statistical package was used for these analyses.

\section{Results And Discussion}

Some properties of the experimental soils are shown on Table 2. The soils are acid with $\mathrm{pH}$ ranging from5.8 at Ofugo, 5.9 at Ogyoma and 6.0 at Abaji-Kpav and Vanam. Clay content was least at Vanam (6\%) while the Abaji-Kpav soil had twice this value (12\%) and was highest. The soils are loam, loamy sand and sandy loam. Organic matter values were moderate with the Ofugo soil having the least value of $2.03 \%$ and the Vanam soil highest with a value of $9.46 \%$. The total nitrogen values were low with the Abaji-Kpav soil having the least value of $0.07 \%$ while the highest value of $0.11 \%$ was obtained with the Vanam soil. Total oxide content was also highest at Abaji-Kpav and the Vanam soil had the least value. The ECEC values were however least at Ogyoma $\left(3.26 \mathrm{c} \mathrm{mol} \mathrm{kg}^{-1}\right)$ and highest at Vanam $\left(5.03 \mathrm{c} \mathrm{mol} \mathrm{kg}^{-1}\right)$.

Table 2: Some properties of the experimental soils

\begin{tabular}{lllllllll}
\hline LOCATION & $\mathrm{pH}$ & clay & texture & O.M & Total N & ECEC & $\mathrm{Fe}_{2} \mathrm{O}_{3}$ & $\mathrm{Al}_{2} \mathrm{O}_{3}$ \\
\hline Ogyoma & 5.9 & 9 & $\mathrm{~L}$ & 2.13 & 0.09 & 3.26 & 1.2 & 0.9 \\
Ofugo & 5.8 & 11 & LS & 2.03 & 0.08 & 3.97 & 1.1 & 1.3 \\
Abaji-Kpav & 6.0 & 12 & LS & 2.36 & 0.07 & 3.45 & 1.6 & 1.0 \\
Vanam & 6.0 & 6 & SL & 9.46 & 0.11 & 5.03 & 0.5 & 1.1 \\
\hline
\end{tabular}

Selected P fractions of the experimental locations are shown on Table 3: Total P was highest at Ofugo $448.6 \mathrm{mg} \mathrm{kg}^{-1}$ while the least value of $275.4 \mathrm{mg} \mathrm{kg}^{-1}$ was obtained with the Abaji-Kpav soil. Organic P values followed the same trend and generally constituted about $48 \%$ of the total P. Bray-1 P was least at Ofugo (2.1 mg $\left.\mathrm{kg}^{-1}\right)$ and highest at Vanam $\left(9.0 \mathrm{mg} \mathrm{kg}^{-1}\right)$. Olsen $\mathrm{P}$ was however least at Vanam with a value of $2.1 \mathrm{mg} \mathrm{kg}^{-1}$ and highest at Ogyoma with a value of $7.3 \mathrm{mg} \mathrm{kg}^{-1}$.

Table 3: P Fractions of the experimental soils $\left(\mathrm{mg} \mathrm{kg}^{-1}\right)$

\begin{tabular}{llllllll}
\hline Location & Total P & Organic P & Fe-P & Al-P & Ca-P & Bray-1P & Olsen-P \\
\hline Ogyoma & 422.2 & 202.6 & 125 & 55.2 & 39.3 & 5.2 & 7.3 \\
Ofugo & 448.6 & 215.3 & 118.3 & 81.1 & 23.8 & 2.1 & 4.4 \\
Abaji-Kpav & 275.4 & 132.2 & 83.6 & 36.4 & 23.2 & 2.3 & 5.2 \\
Vanam & 318.7 & 152.9 & 91.2 & 32 & 42.1 & 9.0 & 2.1 \\
\hline
\end{tabular}

The effect of $\mathrm{P}$ solution concentration on some agronomic data in the greenhouse in the Ogyoma soil is presented on Table 4. The Ogyoma soil responded to application of $\mathrm{P}$. The pod number, dry matter yield and seed weight increased significantly with increase in solution concentration up to $0.050 \mathrm{mg}^{-1}$ and decreased thereafter. The highest soybean grain yield of $15.3 \mathrm{t} \mathrm{ha}^{-1}$ was obtained at the solution $\mathrm{P}$ concentration of $0.05 \mathrm{mg}$ $\mathrm{kg}^{-1}$. This appear to be the optimum solution $\mathrm{P}$ concentration for soybean in this soil and the quantity of fertilizer $\mathrm{P}$ required to achieve this concentration was calculated as $0.31 \mathrm{~g} \mathrm{~kg}^{-1}$ soil. This is equivalent to $39.56 \mathrm{~kg} \mathrm{P} \mathrm{ha}^{-1}$. The effect of $\mathrm{P}$ solution concentration on the yield parameters in the Ofugo soil is shown on Table5. There was significant response to $\mathrm{P}$ application in all the parameters in terms of yield as the solution $\mathrm{P}$ concentration was increased. The highest number of pods, seed weight and dry matter yield was achieved when the solution $\mathrm{P}$ concentration was $0.075 \mathrm{mg} \mathrm{l}^{-1}$. Soybean grain yield obtained at this level of $\mathrm{P}$ concentration was $13.6 \mathrm{t} \mathrm{ha}^{-1}$. The yield of the crop in terms of all the parameters considered decreased significantly thereafter. The quantity of fertilizer $\mathrm{P}$ required to achieve this concentration was calculated as $0.53 \mathrm{~g} \mathrm{~kg}^{-1}$ soil. This is equivalent to 67.64 $\mathrm{kg} \mathrm{P} \mathrm{ha}{ }^{-1}$. 
Estimating the Phosphate Fertilizer Need Of Soybean (Glycine Max (L) Merr.) In Some Ultisols In

Table 4.: Effect of P Solution Concentration on Yield Parameters $\left(\mathrm{g} \mathrm{pot}^{-1}\right)$ in

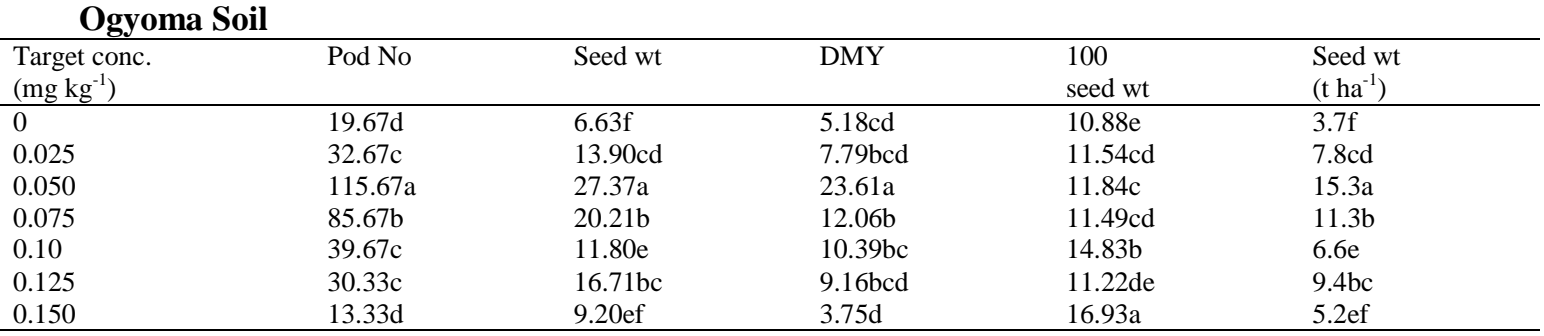

Within each column, means with the same letters are not significantly different according to DMRT. Ofugo Soil

Table 5: Effect of P Solution Concentration on Yield Parameters $\left(\mathrm{g} \mathrm{pot}^{-1}\right)$ in

\begin{tabular}{llllll}
\hline $\begin{array}{l}\text { Target conc. } \\
\left(\mathrm{mg} \mathrm{kg}^{-1}\right)\end{array}$ & Pod No & Seed wt & DMY & $\begin{array}{l}100 \\
\text { seed wt }\end{array}$ & $\begin{array}{l}\text { Seed wt } \\
\left.(\mathrm{t} \mathrm{ha})^{-1}\right)\end{array}$ \\
\hline 0 & $17.33 \mathrm{bc}$ & $2.53 \mathrm{c}$ & $4.82 \mathrm{c}$ & $7.02 \mathrm{e}$ & $1.4 \mathrm{c}$ \\
0.025 & $38.33 \mathrm{~b}$ & $7.58 \mathrm{bc}$ & $7.80 \mathrm{bc}$ & $9.26 \mathrm{~d}$ & $4.2 \mathrm{bc}$ \\
0.050 & $30.0 \mathrm{bc}$ & $13.18 \mathrm{~b}$ & $11.73 \mathrm{~b}$ & $21.44 \mathrm{a}$ & $7.2 \mathrm{~b}$ \\
0.075 & $62.0 \mathrm{a}$ & $24.26 \mathrm{a}$ & $16.45 \mathrm{a}$ & $15.56 \mathrm{~b}$ & $13.6 \mathrm{a}$ \\
0.10 & $32.33 \mathrm{~b}$ & $10.06 \mathrm{bc}$ & $11.26 \mathrm{~b}$ & $15.43 \mathrm{~b}$ & $5.6 \mathrm{bc}$ \\
0.125 & $24.33 \mathrm{bc}$ & $7.00 \mathrm{bc}$ & $5.85 \mathrm{c}$ & $12.67 \mathrm{~d}$ & $3.9 \mathrm{bc}$ \\
0.150 & $9.33 \mathrm{c}$ & $1.85 \mathrm{c}$ & $4.52 \mathrm{c}$ & $9.89 \mathrm{~d}$ & $1.0 \mathrm{c}$ \\
\hline
\end{tabular}

Within each column, means with the same letters are not significantly different according to Duncan Multiple Range Test.

Effect of P solution concentration on the yield parameters in the Abaji-Kpav soil is shown on Table 6. Response to applied $\mathrm{P}$ was observed in all the yield parameters as the solution $\mathrm{P}$ concentration was increased. The highest number of pods, seed weight and dry matter yield was achieved when the solution $\mathrm{P}$ concentration was $0.075 \mathrm{mg} \mathrm{l}^{-1}$; however, this was not significantly different from what was obtained with $0.050 \mathrm{mg} \mathrm{kg}^{-1}$ and $0.025 \mathrm{mg} \mathrm{l}^{-1}$. Besides increasing the solution $\mathrm{P}$ concentration threefold to achieve a solution concentration of $0.075 \mathrm{mg} \mathrm{kg}^{-1}$ does not result in a corresponding threefold increase in yield from what was obtained with 0.025 $\mathrm{mg} \mathrm{l}^{-1}$. The yield of the crop in terms of all the parameters considered decreased significantly thereafter. Optimum yield of $12.8 \mathrm{t} \mathrm{ha}^{-1}$ was however attained at $0.025 \mathrm{mg} \mathrm{kg}^{-1}$. The quantity of fertilizer $\mathrm{P}$ required to achieve this level of solution $\mathrm{P}$ concentration in the soil was estimated as $0.18 \mathrm{~g} \mathrm{~kg}^{-1}$ soil. This is equivalent to $22.97 \mathrm{~kg} \mathrm{P} \mathrm{ha}^{-1}$.

Effect of $\mathrm{P}$ solution concentration on some agronomic parameters in the greenhouse in the Vanam soil is presented on Table 7. The pod number, dry matter yield and seed weight increased significantly with increase in solution concentration up to $0.025 \mathrm{mg} \mathrm{l}^{-1}$ and decreased thereafter. Highest soybean grain yield obtained with this soil was $23.1 \mathrm{t} \mathrm{ha}^{-1}$. The quantity of fertilizer $\mathrm{P}$ required to achieve this level of solution concentration was calculated as $0.02 \mathrm{~g} \mathrm{~kg}^{-1}$ soil. This value is equivalent to $2.55 \mathrm{~kg} \mathrm{P}^{-1}$.

The Vanam soil produced the highest grain yield of $23.1 \mathrm{t} \mathrm{ha}^{-1}$ and was followed by $15.3 \mathrm{t} \mathrm{ha}^{-1}$ (Ogyoma), $13.6 \mathrm{t} \mathrm{ha}^{-1}$ (Ofugo) while the least yield of $12.8 \mathrm{t} \mathrm{ha}^{-1}$ Abaji-Kpav. The total nitrogen values of these soils is in total agreement with this yield trend as the Vanam soil has the highest value and the Abaji-Kpav soil the least. Since $\mathrm{P}$ is the yield limiting nutrient in this crop, availability of nitrogen may have encouraged physiological growth as well as the $\mathrm{P}$ nutrition. A reverse trend was observed with the clay content as the Vanam soil with the least clay content had the highest yield while the Abaji-Kpav soil with the highest clay content had the least yield. Sibbenssen 1981, had earlier observed that soil texture is responsible for variation in phosphate adsorption behavior. Such behavior can be explained by the fact that fine textured soil exposes larger surface area than the coarse textured soils. The fine textured soils could also have stronger reactive sites than the coarse textured soils. Low affinity for P by sandy soils had earlier been reported by (Sibbenssen, 1978). Variations in organic matter content, clay content, $\mathrm{pH}$, phosphate added as fertilizer have been responsible for variations in $\mathrm{P}$ adsorption in soils,(Litaor et al.,2005; Brady and Weil, 2008). In the present study, variation could not be ascribed to such factors as $\mathrm{pH}$ as the $\mathrm{pH}$ of all the soils ranged between 5.8 and 6.0 with a very little difference and might have not affected the variation in phosphate adsorption to a greater extent. Similarly, phosphate added as fertilizers might have little effect as most of the farmers use no (phosphatic) fertilizers. Variations in $\mathrm{P}$ adsorption between the soils could have been due to various reasons such as the initial $\mathrm{P}$ contents of the soils, their clay contents which could have provided the active sites for the adsorption, the organic matter content etc. Holford and Patrick, (1979) however reported that lower adsorption in such surface samples might be owing to occupation of sites in the surface soils by organic anions. The case of Vanam with the highest organic matter content can thus be easily explained. 
Estimating the Phosphate Fertilizer Need Of Soybean (Glycine Max (L) Merr.) In Some Ultisols In

\begin{tabular}{|c|c|c|c|c|c|}
\hline $\begin{array}{l}\text { Target conc. } \\
\left(\mathrm{mg} \mathrm{kg}^{-1}\right)\end{array}$ & Pod No & Seed wt & DMY & $\begin{array}{l}100 \\
\text { seed wt }\end{array}$ & $\begin{array}{l}\text { Seed wt } \\
\left(\mathrm{t} \mathrm{ha}^{-1}\right)\end{array}$ \\
\hline 0 & $24.33 b$ & $1.16 \mathrm{~b}$ & $9.65 b c$ & $5.04 d$ & $6.5 b$ \\
\hline 0.025 & $80.0 \mathrm{a}$ & $22.87 \mathrm{a}$ & $15.52 \mathrm{ab}$ & $18.38 \mathrm{a}$ & $12.8 \mathrm{a}$ \\
\hline 0.050 & $117.67 \mathrm{a}$ & $30.80 \mathrm{a}$ & $23.21 \mathrm{a}$ & $16.51 \mathrm{~b}$ & $17.2 \mathrm{a}$ \\
\hline 0.075 & $98.0 \mathrm{a}$ & $6.56 \mathrm{~b}$ & $7.00 \mathrm{bc}$ & $12.29 \mathrm{c}$ & $3.7 b$ \\
\hline 0.10 & $18.33 b$ & $1.97 \mathrm{~b}$ & $4.74 \mathrm{c}$ & $4.68 \mathrm{~d}$ & $1.1 \mathrm{~b}$ \\
\hline
\end{tabular}

Within each column, means with the same letters are not significantly different according to DMRT.

Table 7: Effect of P Solution Concentration on Yield parameters $\left(\mathrm{g} \mathrm{pot}^{-1}\right)$ in Vanam Soil

\begin{tabular}{|c|c|c|c|c|c|}
\hline $\begin{array}{l}\text { Target conc. } \\
\left(\mathrm{mg} \mathrm{kg}^{-1}\right)\end{array}$ & Pod No & Seed wt & DMY & $\begin{array}{l}100 \\
\text { seed wt }\end{array}$ & $\begin{array}{l}\text { Seed wt } \\
\left(\mathrm{t} \mathrm{ha}^{-1}\right)\end{array}$ \\
\hline 0 & $83.33 b$ & $32.66 \mathrm{c}$ & $26.36 \mathrm{~b}$ & $17.45 \mathrm{c}$ & $18.3 \mathrm{c}$ \\
\hline 0.025 & $124.33 \mathrm{a}$ & $41.27 \mathrm{a}$ & $31.90 \mathrm{a}$ & $13.43 \mathrm{e}$ & $23.1 \mathrm{a}$ \\
\hline 0.050 & $108.33 \mathrm{a}$ & $36.73 b$ & $27.16 \mathrm{~b}$ & $16.72 d$ & $20.6 b$ \\
\hline 0.075 & $70.33 b c$ & $28.71 d$ & $22.58 b c$ & $27.81 b$ & $16.1 \mathrm{~d}$ \\
\hline 0.10 & $62.67 \mathrm{~cd}$ & $23.04 \mathrm{e}$ & $18.13 \mathrm{~cd}$ & 28.61a & $12.9 \mathrm{e}$ \\
\hline 0.125 & $47.67 d$ & $20.11 \mathrm{e}$ & $15.22 \mathrm{de}$ & $9.68 \mathrm{~g}$ & $11.3 \mathrm{e}$ \\
\hline 0.150 & $26.67 \mathrm{e}$ & $12.62 \mathrm{f}$ & $13.08 \mathrm{ef}$ & $8.98 \mathrm{~h}$ & $7.1 \mathrm{f}$ \\
\hline 0.175 & $20.0 \mathrm{e}$ & $11.18 \mathrm{f}$ & $10.03 \mathrm{f}$ & $11.81 \mathrm{f}$ & $6.3 \mathrm{f}$ \\
\hline
\end{tabular}

Within each column, means with the same letters are not significantly different according to Duncan Multiple Range Test.

Table 8 shows the effect of solution $\mathrm{P}$ concentration on yield parameters from the field experiment conducted at Vanam. This shows that the highest value of $12.84 \mathrm{~kg}$ per plot was obtained at solution concentration equivalent to $2.0 \mathrm{SPC}$. This is equivalent to 5.14 tons per hectare but was however not significantly different from 4.40 tons per hectare obtained with a solution concentration equivalent to 1.0 SPC. The control, (0.0 SPC) and $0.5 \mathrm{SPC}$ treatments did not differ significantly from each other but had yield values that were significantly lower than the other treatment levels. No significant difference was observed in terms of dry matter yield in all the treatments. For the one hundred seed weight, $11.29 \mathrm{~kg}$ was obtained at $1.0 \mathrm{SPC}$ which did not differ significantly from $11.18 \mathrm{~kg}$ obtained with 0.5 SPC. $2.0 \mathrm{SPC}$ had $10.683 \mathrm{~g}$ which did not differ significantly from 0.5 SPC but was significantly lower than 1.0 SPC. The control, $(0.0$ SPC) produced the least value of $10.22 \mathrm{~kg}$ which was significantly lower than all the other treatment levels except $2.0 \mathrm{SPC}$ that did not show significant difference with this value. The estimated SPC from the pot experiment thus produced the optimum yield for the crop at this location.

Table 8: Effect of Solution P Concentration on Yield Parameters in the Field Trial at Vanam

\begin{tabular}{lllll}
\hline $\begin{array}{l}\text { Target conc. } \\
\left(\mathrm{mg} \mathrm{kg}^{-1}\right)\end{array}$ & Seed wt $(\mathrm{kg})$ & DMY $(\mathrm{kg})$ & $\begin{array}{l}100 \\
\text { Seed wt }(\mathrm{g})\end{array}$ & $\begin{array}{l}\text { Seed wt. } \\
\left.(\mathrm{t} \mathrm{ha})^{-1}\right)\end{array}$ \\
\hline $0.0 \mathrm{SPC}$ & $6.92 \mathrm{~b}$ & $1.97 \mathrm{a}$ & $10.22 \mathrm{c}$ & $2.77 \mathrm{~b}$ \\
$0.5 \mathrm{SPC}$ & $7.52 \mathrm{~b}$ & $2.71 \mathrm{a}$ & $11.18 \mathrm{ab}$ & $3.01 \mathrm{~b}$ \\
$1.0 \mathrm{SPC}$ & $11.01 \mathrm{a}$ & $2.98 \mathrm{a}$ & $11.29 \mathrm{a}$ & $4.40 \mathrm{a}$ \\
$2.0 \mathrm{SPC}$ & $12.84 \mathrm{a}$ & $2.86 \mathrm{a}$ & $10.68 \mathrm{bc}$ & $5.13 \mathrm{a}$ \\
\hline
\end{tabular}

Within each column, means with the same letters are not significantly different according to Duncan Multiple Range Test.

Highest soybean yield was obtained with the Vanam soil $\left(23.1 \mathrm{t} \mathrm{ha}^{-1}\right)$ at an SPC of $0.025 \mathrm{mg} \mathrm{kg}^{-1}$ and was followed by the $17.3 \mathrm{t} \mathrm{ha}^{-1}$ obtained with the Abaji-Kpav soil at the same SPC. Ogyoma followed with $15.3 \mathrm{t}$ $\mathrm{ha}^{-1}$ at $0.050 \mathrm{mg} \mathrm{kg}^{-1} \mathrm{SPC}$ while the Ofugo soil produced the least yield of $14 \mathrm{t} \mathrm{ha}^{-1}$ at $0.075 \mathrm{mg} \mathrm{kg}^{-1}$.Optimum yield in all the soils decreased as the SPC values increase. Amount of fertilizer P required to achieve the SPC also varied among the soils due probably to the native P content and the soil properties and increased as the SPC increased. It was concluded that the highest $\mathrm{P}$ fertilization would be required at Ofugo (67.64 $\mathrm{Kg} \mathrm{P} \mathrm{ha}^{-1}$ ), Ogyoma (39.56 Kg P ha $\left.{ }^{-1}\right)$. Abaji-Kpav $\left(22.97 \mathrm{Kg} \mathrm{P} \mathrm{ha}^{-1}\right)$ and Vanam $\left(2.55 \mathrm{Kg} \mathrm{P} \mathrm{ha}^{-1}\right)$ would require the least.

\section{References}

[1]. Adetunji M.T (1995). Equilibrium phosphate concentration as an estimate of phosphate needs of maize in some tropical Alfisols. Journal of tropical Agriculture (Trinidad) 72:285-289

[2]. Aduayi, E.A,V.O. Chude, B.A. Adebusuyi and S.O. Olayiwola eds.(2002). Fertilizer use and management practices for crops in Nigeria. $3^{\text {rd }}$ ed. S.B.Garko international limited. 67-70.

[3]. Barrow, N.J and T.C Shaw. (1975). The slow reactions between anions and soil. 2: Effect of temperature and time on the decrease in phosphate concentration in soil solution. Soil Sci. 119: 167-177

[4]. Bouyoucos, G.H.( 1951). A recalibration of the hydrometer method for testing mechanical analysis of soils. Agronomy Journal. 43:434-438 
[5]. Brady, N.C. and R. R. Weil. (2008). Elements of the Nature and Properties of Soils, $4^{\text {th }}$ ed. Pearson Education, Inc. Upper saddle River NJ 726-731.

[6]. Bray, R.H and L.T.Kutz (1945). Determination of total, Organic and Available forms of phosphorus in soils. Soil Science, 59:45-59

[7]. Chang, S.C. and M.L. Jackson (1957). Fractionation of soil phosphorus. Soil science 84: $133-144$.

[8]. Dear, B. S., Helyar, K.R., Muller, W.J and Loveland, B. (1992). The P fertilizer requirements of subterranean clover, and the soil P status, sorption and buffering capacities from two P analyses, Australian Journal of Soil Research. 30: 27-44

[9]. Enwezor, W.O and Moore,A.W. (1966). Soil Science. 102,322.

[10]. Federal Department of Agricultural Land Resources (1990). Soils Report: IV: 76-132

[11]. Holford, I.C.R and W.H Patrick jnr. (1979). Effect of reduction and pH changes on phosphate sorption and mobility in an acid soil. Soil Science Society of America journal. 43: 292-297

[12]. Litoar, M. I., O. Reichmann, A. Haim, K. Auerswald and M. Shenker. (2005). Sorption characteristics of phosphorus in peat soils of a semi arid altered wetland. Soil science society of America journal 69: 1658-1665

[13]. Mebra, O.P and M.I Jackson (1960). Iron oxide removal from soils and clays by a dithionate-citrate system buffered with sodium bi carbonate. Proceedings of $7^{\text {th }}$ National Conference on clays and clay minerals pp 317-327. Peragon press, New York.

[14]. Mehra N.O, Legg, J.C, Goring CAI \& Black CA (1954). Determination of organic phosphorus in soils: 1. Extraction methods. Soil Science Society of America Proceedings 18: 443-449

[15]. Murphy,J and J.P Riley (1962). A modified single solution method for determination of phosphorus in natural waters. Anal. Chem.. Acta. 27:31-36

[16]. Olsen, S.R, L.T. Cole, F.S Watanabe and L.A Dean (1954). Estimation of available phosphorus in soils by extraction with sodium bicarbonate. U. S Department of Agriculture circ. 939

[17]. Page A.L., R.H Miler, and D.R Keeney (eds) (1982). Methods of soil analysis, part 2, Chemical and Microbiological properties $2^{\text {nd }}$ edition, Agronomy 9: Soil Science Society of America. Madison, USA.

[18]. Peterson, G.W and R. B. Corey (1966). A modified Chang and Jackson procedure for routine fractionation of inorganic soil phosphorus. Soil Science Society of America proceedings 30: 563-565

[19]. Sibenssen, E. (1978). An investigation of the anion exchange resin method for soil phosphate extraction. Plant and soil 50, $305-321$.

[20]. Udo, E.J. and J.A Ogunwale, (1977). Soil Science Society of America journal. 41,1141

[21]. Uzu, F.G., A.S.R Juo and A.A.A Fayemi,. (1975) Soil Science. 120,212

[22]. Walkley, A., and I. A. Black. (1934). An examination of Degtjareff method for determining soil organic matter and proposed modification of the chromic acid in soil analysis.1. Experimental soil science 79: 459-465.

[23]. Watanabe, F.S and S.R. Olsen (1965). Test of an ascorbic acid method for determination of phosphorus in water and NaHCO extracts from soils. Soil Science Society of America proceedings 29: 677

[24]. Yusuf I.A and A.A Idowu (2001). NPK requirement for soybean production in the Southern Guinea Savannah. Tropical oil seeds journal 6:50-56 